\title{
Hvem får mest?
}

I det nye året har vi dykket ned i arkivene og sett hva Tidsskriftet publiserte for akkurat 100 år siden. Mye av $\mathrm{nr}$. 1/1916 omhandlet difteri, men resten var meddelelser, årsberetninger o.l. Under vignetten «Lægeforhold ute og hjemme» sto en notis der man sammenlignet legelønn med veterinærlønn (Tidsskr Nor Lægeforen 1916; 36: 29-30).

\section{Lonninger for dikstriktslagestillinger og amtsdyrlagestillinger}

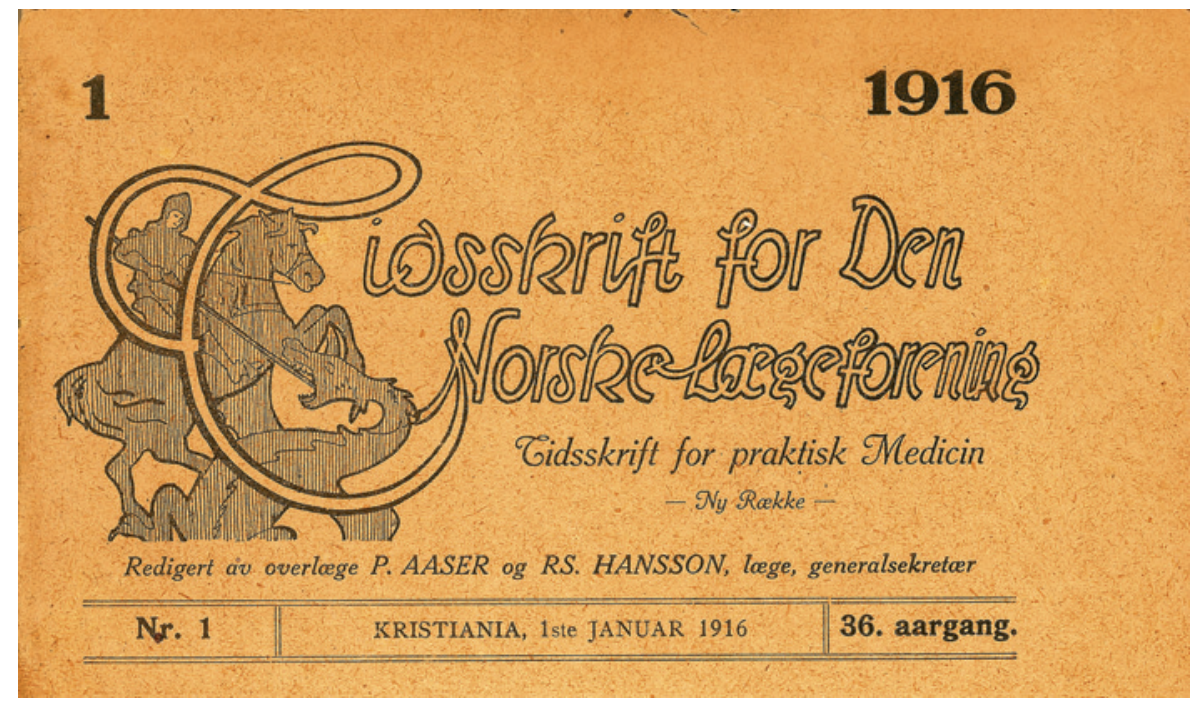

Det kan av og til ha litt interesse at sammenligne distriktslægernes ansættelsesvilkaar med amtsdyrlægernes. Vi hitsætter derfor nedenfor ansættelsesvilkaarene for en den 14de december 1915 kundgjort amtsdyrlægestilling paa Østlandet. Kundgjørelsen lyder slik:

Ansøkninger om den ledige Storelvedalen amtsdyrlægebestilling kan indsendes hertil inden 4 uker fra i dag, ledsaget av attester i bekræftet stand.

Den aarlige avlønning utgjør av distriktet kr. 500,00, av amtskommunen kr. 300,00, hvortil kommer det til enhver tid paaregnelige statsbidrag, der for tiden utgjør kr. 800,00. Dessuten erholdes efter 5 aars tjeneste et alderstillæg, stort kr. 50,00, av distriktet, kr. 50,00 av amtet samt paaregnelige statsbidrag.

Distriktet, der omfatter Storelvedalen og Sollien herreder, har en matrikulskyld av mark 1527,56 og hadde ved siste jordbrukstælling 370 hester, 2761 storfæ og 1513 smaafæ og svin.
Dyrlægen vil bli tilpligtet at gjøre indskud i et oprettendes pensions- og understøttelsesfond, likesom han ansættes med forpligtelse til at finde sig i mulig omregulering av distriktet.

Gjensidig opsigelsesfrist 6 maaneder.

Stillingen blir at tiltræ fra 1ste april 1916.

Hedmarkens amt den 14de december 1915.

Den aarlige avlønning er altsaa: 1600 kroner med 1 alderstillæg (à kr. 150) efter 5 aars tjeneste, mens mange distriktslægestillinger paa Østlandet lønnes med 1200 kroner og 3 alderstillæg à 200 kroner efter 3, 6 og 9 aars tjeneste.

Vi maa samtidig utrykkelig gjøre opmerksom paa, at dyrlægernes ansættelsesvilkaar iøvrig er meget uheldige, bl.a. derved at herrederne har indstillingsret, jvfr. forresten direktør dr. Malms artikel: $\mathrm{i}$ «Norsk Veterinærtidsskr» 1915 (s. 233 o. flg). 